\title{
CAMEL CARTING SUPERIOR OPTION THAN BULLOCK CARTING IN DESERT Dr. Champak Bhakat
}

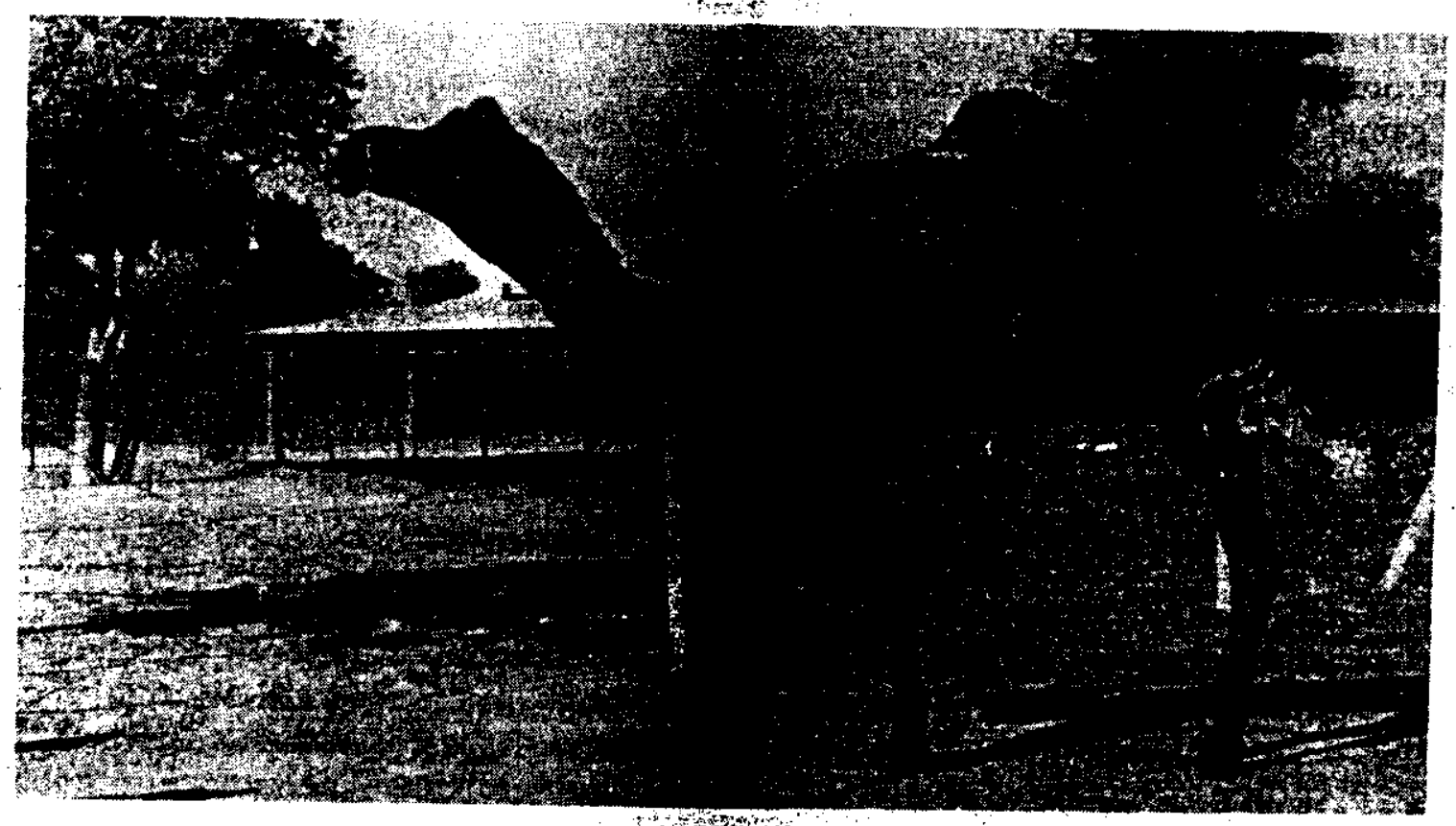

As Thar desert land region is prone to frequent draught, the small and marginal farmers of this area depend on livestock enterprise $4+30$ for their sustenance because animal huseen the crop sector and draught animal add on such degraded land is successfur the of maintaining draught aniis basically a stable protective long-term viability, pability and income generating caparbing cajitable enterprise. Heifer Project International pability and income generating capacity. The (HPI), a private non-profit development agency livestock should be compatible with crop cultit is assisting tribal minorities who seek gainful vation instead of competing with it for land and employment using camel for transporting agriwater resource. Camel rearing enterprise fits cultural and industrial products. There has been well with such requirements. The total world constant increase of camel driven carts even camel population is estimated to be $19.32 \mathrm{mil}$, around big cities. Evaluation of IRDP in the arid lion of which India has 1.03 million.

In fact animal drawn carts continue to income of the beneficiaries was one of the highplay a crucial role in the farm economy of the est amongst people who has given loan for the country as a cheap mode of transportation of purchase of camel and camel carts. In comparidifferent agricultural products. Actually, the son to other livestock species camel remained livelihood of maximum cart owner is dependent neglected until this century when it draws atonly on this type of transport system. Animal tention because of it's unique adaptive characcarting provides gainful source of employments teristics for survivability in the harsh conditions

"Scientist (S.S.) and Inchar ge Camel Management Unit, National Resear ch Centre on Camel, Bikaner - 334001, Rajasthan. 
of the desert Eco-system. The camel "Ship of the desert" uses various adaptive mechanism rather than bullock for survival in the desert. For instance cattle in the central desert of Australia with daily temperature of $40 \mathrm{o} C$ were reported to have died without water in four days while camels survived for more than 15 days in the same environment. It has been estimated that a well-fed camel could carry some six months energy on it's back while cattle are unlikely to have more than two-three months. Therefore, camel can tolerate high temperature, solar radiation and water deprivation and subsists on poor quality, thorny, vegetation. Since 85 per cent of the gross cultivated area of the Bikaner district is non-irrigated camel carts hold a significant potential for financing. Camel energy is not only cost effective but also profitable and remunerable. It is therefore, necessary to investigate the main features and economics of camel and bullock carting in order to know whether or not these animals are efficiently utilised by farmers and to find out the economic viability of both type of carting system in hot arid of Thar desert.

\section{Salient feature of camel and bullock carting systems}

In the arid district land is duny and soils are low in nitrogen and organic matter content: It is natural eroded by winds during summer and the crop yield are low and unstable. Some of animal keepers follow a transmigratory system of animal management. Animal husbandry in this region depends on the economic and social aspects of land use management. Animal drawn carting system is very much used in hot arid Thar region for all kinds of material $l^{t}$ trans portation within the cities or from nearby vil-? lages to cities and vice-versa. Both type of animal keepers are using their cart to transport different materials viz. crop yields, grain bags, fuel wood, fodder, bhusa, water, gas, cylinders, synthetic yarn and building materials etc. Camel rearing in Rajasthan is animal power for pulling a cart. Two-wheeled pneumatic tyre wooden cart is made up of sheesham, babool, neem, desi sagwan etc.
The ayerage working life period of camel (14.50 year) is higher as compared to bullock (10.00, year) used under carting operation where as the average life period of animal drawn cart is almost same. Maximum farmers involve themselves for the carting operation in both cases But fewarealso keeping some hired person by which they perform this operation. The average cost of camel cart is about 17 per cent high as compared ito bullock cart. Maximum farmers preferre male camel (96.43 per cent) rather thang eration.The a verage working days in a year are almost equaling on thype of carting system. The average wor $/ 7$ s ime hours/day for male cart camel is 9.25. in o o female camel is 8.00 where as the bullocks o 18,65 The average weight / load carrying by bullockcart (8.00 quintals) is quite low o compara uto camel cart (14.5 quintals). Althorg wito argof of of cart camel

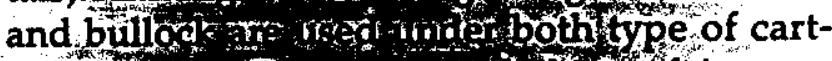
ing, system, the atreragedaly total income from camel otiting is estimated to be higher than bullockcarting The average number of grain bagstransporting per round are double in case of camel carting (18.00) as compared to bullock carting $(9 ; 00)$ y here as the average estimated carry less on camel carthan bullock cart Most of the farmers are purchising their draftanimal as well as cart on cash payment followed by in-

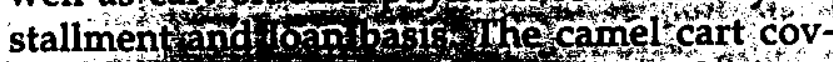
ered max mor tretrogrance $(2145 \mathrm{~km})$ per day than 6 ullo, 1 cart $(485 \mathrm{~km})$,

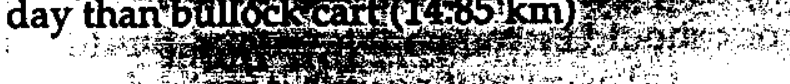

Economicanalysis of

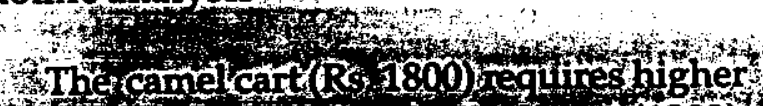

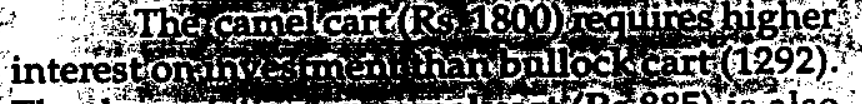
The depreciationo o chel cart (Rs 885) is also high as compared to bulock cart $\left(\mathrm{Rs}^{\mathrm{T}} 720\right)$ when the Junk falue o woden cart is considered @ 10 percentof frerage intial cost. The expenditures for ths w ance of camel (Rs 449) is some what more than buillock (Rs 298), when premium rateit consleredo per cent of average initial cost along $\mathrm{With}$ overall service tax @ 5 per cent, etc. The insurance charges for cart is estimated to be higher in case of camel (Rs. 147) 


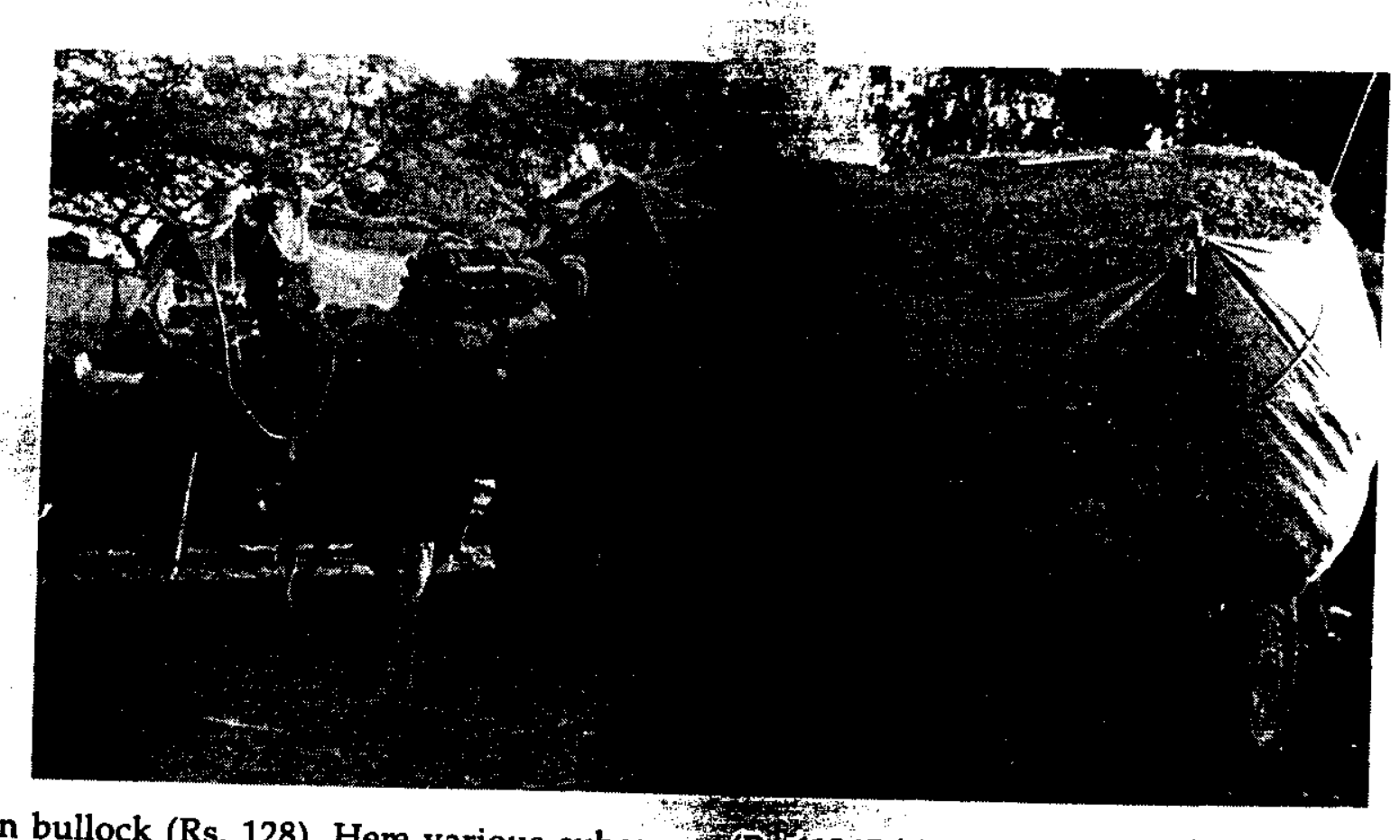

than bullock (Rs. 128). Here various subcom

ponents like basic value (Rs. 30/-), liabilities (Rs.61345/-) as compared to bullock carting (Rs.5/-), one per cent of average actual of cart along with five per cent overall value ing (Rs.21889/-) than bullock carting (Rs. 7971/ six, etc. are considered. The overall tot service 4 ). The pay back period (PBP) is almost double cost is high in camel carting (3331) than bused in case of bullock carting (1.81 year) as comlock carting (Rs 2438) due to higher initial- pared to camel carting 0.91 year), where as the vestment.

The different components of variable case of camel carting (1.55) as compared to bulcost are considered on carting (1.20).

ing and maintenand on yearly basis. The repair 3

is high as contenance cost of camel cart (Rs 1550) Consion

is high as compared to bullock cart (Rs. 1450),

tyre puncture, subcomponents like repairing of $x^{2}$, To ensure a regular income and suffiing/replacement replacement of tire and repair-tient food for farmers and better living stanconsidered. The expenterent body parts, etc are thards, it is necessary to go for some other altenance (feeding expenses towards yearly main- ternate which will provide more income and 15330) and bulland health cover) to camel ( $R$ s femployment to the unemployment youth of city area requireck (Rs. 14965) are used in the former's family. Such enterprises include 1-2 times Rs.800. The total and yearly expenditure is tholds practical values for cost effectiveness, high in bullock carting (Rs 36929 ) thed to be 9 sustainable, environmentally friendly and carting (Rs 36125) mainly because then camelosocio culturally acceptable. In fact camels are ing component Shoeing is not require that shoe- life line of the rural population in the remote camel due to its well adapted anatomite at for village of Thar desert. The idea of ture of foot pad. Camels have soft elastiction sustainability of agriculture and livestock with thick skin around which is in long sandy terrains. The total good for travel of time, money, resource and family labours camel carting is Rs. 39456/- and forpenditure for thof the farmers. Due to short pay back period ing is Rs. 39367 which are almor bullock cart-and higher benefit cost ratio camel carting is earning from camel carting is quite high carting for small dry land farmer.(IA) 